Issued by Sandia National Laboratories, operated for the United States Department of Energy by Sandia Corporation.

NOTICE: This report was prepared as an account of work sponsored by an agency of the United States Government. Neither the United States Government, nor any agency thereof, nor any of their employees, nor any of their contractors, subcontractors, or their employees, make any warranty, express or implied, or assume any legal liability or responsibility for the accuracy, completeness, or usefulness of any information; apparatus, product, or process disclosed, or represent that its use would not infringe privately owned rights. Reference herein to any specific commercial product, process, or service by trade name, trademark, manufacturer, or otherwise, does not necessarily constitute or imply its endorsement, recommendation, or favoring by the United States Government, any agency thereof, or any of their contractors or subcontractors. The views and opinions expressed herein do not necessarily state or reflect those of the United States Government, any agency thereof, or any of their contractors.

Printed in the United States of America. This report has been reproduced directly from the best available copy.

Available to DOE and DOE contractors from

U.S. Department of Energy

Office of Scientific and Technical Information

P.O. Box 62

Oak Ridge, TN 37831

Telephone: (865)576-8401

Facsimile: (865)576-5728

E-Mail: reports@adonis.osti.gov

Online ordering: http://www.doe.gov/bridge

Available to the public from

U.S. Department of Commerce

National Technical Information Service

5285 Port Royal Rd

Springfield, VA 22161

Telephone: (800)553-6847

Facsimile: (703)605-6900

E-Mail: $\quad$ orders@ntis.fedworld.gov

Online order: http://www.ntis.gov/ordering.htm

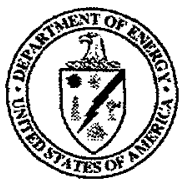




\section{DISCLAIMER}

Portions of this document may be illegible in electronic image products. Images are produced from the best available original document. 
SAND2000-1950

Unlimited Release

Printed August 2000

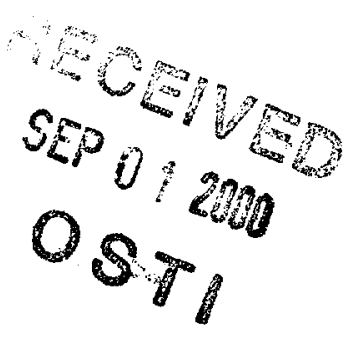

\title{
DOE-EM SNF Transportation System
}

\author{
Nicole L. Breivik and \\ Douglas J. Ammerman \\ Transportation Safety and Security Analysis Dept. \\ Sandia National Laboratories \\ P.O. Box 5800 \\ Albuquerque, NM 87185-0718
}

\begin{abstract}
The effects of five possible handling accidents on a proposed DOE-EM National Spent Nuclear Fuel Program (NSNFP) transportation cask were analyzed. Four of the five accidents were from a drop height of 72 in., impacting onto an unyielding surface, without impact limiters. These accidents were beyond the required regulatory conditions for transportation packaging. The four accidents were a side drop impacting on a lifting trunnion, a corner drop impacting on the lid, a corner drop impacting on the bottom of the cask, and a slap-down of the cask from one lifting trunnion onto a second trunnion. The remaining accident analyzed was an impact of the horizontally oriented cask onto a punch as described in the hypothetical accident conditions in 10CFR71.73(c)(3). All analyses were conducted using a transient dynamic finite element code with nonlinear material properties. Results indicate that the puncture type accidents, that is, the horizontal drop onto a punch, the side drop onto a lifting trunnion, and the slap down from one lifting trunnion onto a second trunnion, do not cause tearing of the outer cask shell or deformations that are likely to cause leaking at the lid closure region. Likewise, the corner drop on the bottom of the cask did not result in outer shell tearing or closure region leakage. However, analysis of the corner drop onto the cask lid indicated a potential leak at the closure region. Also, the deformation of the closure bolts was examined and suggested probable bolt failure.
\end{abstract}




\section{Contents}

List of Figures

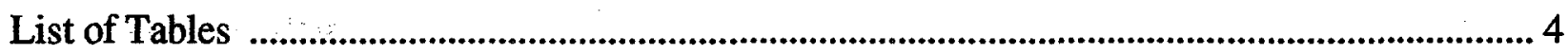

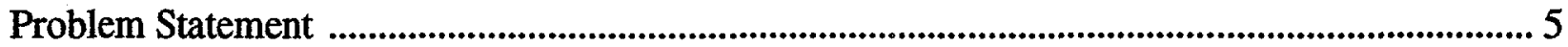



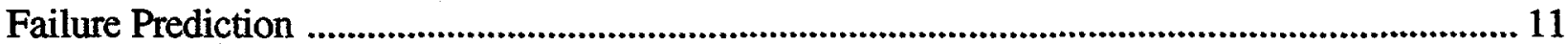



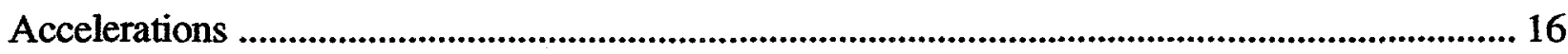

Summary and Conclusions

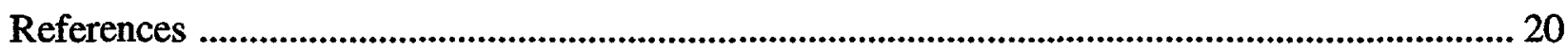




\section{List of Figures}

Figure 1 - Finite element model for case (1), side drop onto the lifting trunnion .......................... 7

Figure 2 - Finite element model for case (2), corner drop onto the lid ....................................... 8

Figure 3 - Finite element model for case (3), horizontal drop onto a punch ................................... 9

Figure 4 - Finite element model for case (4), corner drop onto cask bottom ............................... 10

Figure 5 - Finite element model for case (5), slap-down impact onto second trunnion ............... 10

Figure 6 - Stiffness of 304L stainless steel .....................................................................................11

Figure 7 - Results for case (1), side drop onto the lifting trunnion ............................................ 12

Figure 8 - Results for case (2), corner drop onto the lid ........................................................... 13

Figure 9 - Opening displacement at o-ring location for case (2), comer drop onto the lid

Figure 10 - Bolt stretching results for case (2), corner drop onto the lid .................................... 14

Figure 11 - Results for case (3), horizontal drop onto a punch ...................................................... 15

Figure 12 - Results for case (4), corner drop onto cask bottom ................................................ 16

Figure 13 - Results after impact of first trunnion for case (5), slap-down impact onto second trunnion

Figure 14 - Results after impact of second trunnion for case (5), slap-down impact onto second trunnion

Figure 15 - Acceleration for case (1), side drop onto the lifting trunnion ................................... 19

Figure 16 - Acceleration for case (2), corner drop onto the lid ............................................... 19

Figure 17 - Acceleration for case (3), horizontal drop onto a punch ............................................. 20

Figure 18 - Acceleration for case (4), corner drop onto cask bottom ............................................ 20

Figure 19 - Acceleration for case (5), slap-down impact onto second trunnion ........................... 21 


\section{List of Tables}

Table 1: Material properties .............................................................................................................. 6

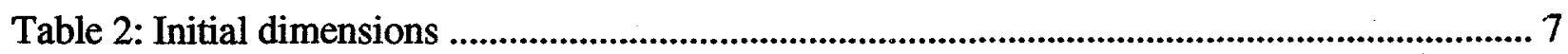




\section{Problem Statement}

Assess the effect of five possible handling accidents on a proposed DOE-EM National Spent Nuclear Fuel Program (NSNFP) transportation cask. Four of these accident scenarios are nonregulatory handling accidents, so the impact limiters are assumed to be separate from the cask during these events and are therefore not included in this study. The five possible handling accidents or cases were defined by the customer to be:

(1) Analyze a side drop onto an unyielding surface from an elevation of 72 in., impacting on the lifting trunnion. Assess the integrity of the outer and inner shells.

(2) Analyze a corner drop onto an unyielding surface from an elevation of 72 in. Let the lid make the initial contact, and assess the integrity of the closure region due to deformations.

(3) Analyze an impact of the horizontally oriented cask onto a punch from an elevation of $40 \mathrm{in}$., as described in the hypothetical accident conditions in10CFR71.73(c)(3). Assess the integrity of the outer and inner shells.

(4) Analyze a corner drop onto an unyielding surface from an elevation of $72 \mathrm{in}$. Let the bottom of the cask make the initial contact, and assess the integrity of the outer shell, keeping in mind that the actual construction will include a longitudinal weld in the outer shell.

(5) Analyze the slap-down of the cask onto an unyielding surface. Begin with the cask oriented 5 degrees from horizontal, then drop the cask from an elevation of $72 \mathrm{in.}$ Allow the lifting trunnion to make initial contact, followed by a slap-down of the other trunnions onto the unyielding surface. Assess the integrity of the outer and inner shells.

Note that a 72 in. drop onto an unyielding surface is outside of the regulatory envelope for transportation packaging of this size.

\section{Approach}

The required analyses were conducted using an explicit transient dynamic finite element code called PRONTO [1], which was developed at Sandia National Laboratories. Assumed material properties are given in Table 1. An elastic-plastic power law hardening model was used to represent the stainless steel and lead materials. The equations describing this are given by Eq. 1,

$$
\begin{array}{lll}
\sigma=E \varepsilon & \text { for } & \sigma<\sigma_{y} \\
\sigma=\sigma_{y}+A\left\langle\varepsilon_{p}-\varepsilon_{L}\right\rangle^{n} & \text { for } & \sigma>\sigma_{y}
\end{array}
$$

where $\sigma$ is the stress, $\sigma_{y}$ is the yield stress, $\varepsilon$ is the elastic strain, $\varepsilon_{p}$ is the plastic strain, and $\varepsilon_{L}$ is the Lüder's strain. The hardening constant $A$ and hardening exponent $n$ are determined by fitting a curve to experimental data. 
The punch, used in accident case (3), and bolt steel were modeled using an elastic-plastic material model, as described by Eq. 2 .

$$
\begin{array}{lll}
\sigma=E \varepsilon & \text { for } & \sigma<\sigma_{y} \\
\sigma=\sigma_{y}+A \varepsilon_{p} & \text { for } & \sigma>\sigma_{y}
\end{array}
$$

Table 1: Material properties

\begin{tabular}{|c|c|c|c|c|}
\hline Property & $\begin{array}{c}\text { 304L Stainless } \\
\text { Steel } \\
\text { (inner shell, } \\
\text { outer shell, lid, } \\
\text { trunnion, } \\
\text { secondary } \\
\text { containment } \\
\text { vessel*) }\end{array}$ & $\begin{array}{c}\text { Lead } \\
\text { (shield material) }\end{array}$ & $\begin{array}{c}\text { Mild Steel } \\
\text { (punch) }\end{array}$ & Bolt Steel \\
\hline \hline Density (lb/in ${ }^{3}$ ) & $0.286^{*}$ & 0.4134 & 0.286 & 0.286 \\
\hline $\begin{array}{c}\text { Young's Modulus } \\
E \text { (psi) }\end{array}$ & $28 \times 10^{6}$ & $2 \times 10^{6}$ & $30 \times 10^{6}$ & $30 \times 10^{6}$ \\
\hline Poissons' Ratio & 0.27 & 0.27 & 0.27 & 0.3 \\
\hline $\begin{array}{c}\text { Yield Stress } \\
\sigma_{y} \text { (psi) }\end{array}$ & 28000 & 1000 & 42000 & 105000 \\
\hline $\begin{array}{c}\text { Hardening Con- } \\
\text { stant } A \text { (psi) }\end{array}$ & 192746 & 800 & 160000 & 30000 \\
\hline $\begin{array}{c}\text { Hardening Expo- } \\
\text { nent } n\end{array}$ & 0.74819 & 0.5 & & \\
\hline Luder's Strain $\varepsilon_{L}$ & 0 & 0 & & \\
\hline
\end{tabular}

* For the secondary containment vessel, the density was modified to give a total container weight of 160 tons.

For analyses of the five different accident cases, five different finite element models were developed. The region of interest for each case is modeled with fine detail, while the remainder of the cask is less detailed. In all cases, the external neutron shielding was ignored as this component does not contribute to the structural resistance of the cask. Dimensions of the cask are given in Table 2. 
Table 2: Initial dimensions

\begin{tabular}{|c|c|}
\hline mass & 160 tons \\
\hline inner shell thickness (stainless steel) & $1.0 \mathrm{in.}$ \\
\hline lead shielding thickness & $4.25 \mathrm{in.}$ \\
\hline outer shell thickness (stainless steel) & $2.0 \mathrm{in.}$ \\
\hline outer radius & $44.0625 \mathrm{in.}$ \\
\hline length & $228 \mathrm{in}$. \\
\hline punch diameter & 6 in. \\
\hline drop height & 40 in. (onto punch) \\
& 72 in. (all other cases) \\
\hline
\end{tabular}

The finite element model for case (1) is shown in Fig. 1. Due to the symmetry of the cask and loading, only half of the cask was modeled. The entire model was constructed of three-dimensional hexahedral elements. The attachment of the trunnion into the outer shell was accomplished by assuming a flat strip along the length of the cask. An end view of this flat strip is shown in Fig. 1. The flat strip was not expected to alter the results, and was incorporated only to simplify the building of the model. The trunnion was attached to the cask body in the location of the specified welds. The secondary containment vessel was modeled with the correct dimensions, but with few details. The density of the secondary containment vessel shell walls was adjusted to represent the weight of the secondary containment vessel and contents combined. This will lead to exaggerated deflections and stresses in the secondary containment vessel, but will provide a close approximation of the loading to the primary containment vessel that is being analyzed here. The analysis simulated a cask dropped from a height of 72 in.

SIDE VIEW

END VIEW

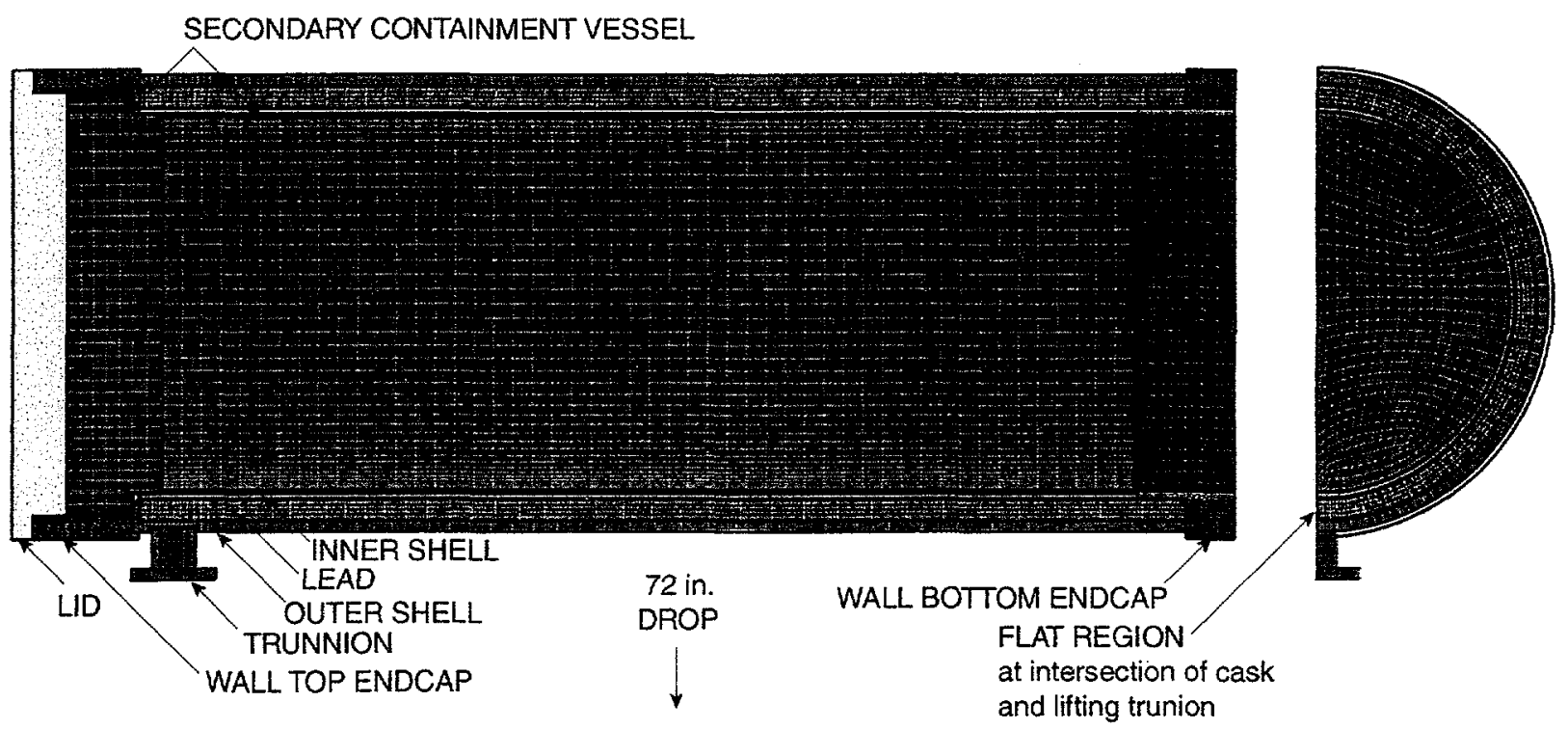

Figure 1 - Finite element model for case (1), side drop onto the lifting trunnion 
The finite element model for case (2) is shown in Fig. 2. A half-symmetric model was again utilized, The outer shell and the upper portion of the inner shell were modeled using shell elements. Shell elements are more computationally efficient, and provide accurate depiction of the bending behavior of the shells. They are not well suited for cases where there is compression through the thickness of the layer being modeled, so the lower portion of the inner shell is modeled with hexahedral elements. The bolts are shown in the expanded portion of the figure. The shank of the bolt was modeled with four elements along the length, to allow for correct tension and necking behavior. Because the bolts were modeled with a square cross section, the bending and shearing behaviors of the bolts were inaccurate. The mass of the secondary containment vessel and the contents were combined and grouped into the shell walls of the secondary containment vessel. The tilt angle of the cask was chosen so that the geometric center of the cask was aligned vertically over the impact corner of the cask. The analysis simulated a drop height of $72 \mathrm{in}$.

The finite element model for case (3) is shown in Fig. 3. This model represents one quarter of the cask, since it is symmetric with respect to two planes. The 6 in. diameter punch is assumed to hit at the midspan of the shell wall, far from either end of the cask. This assumption allows a simplified model which neglects the end details of the cask and instead lumps the missing mass into an

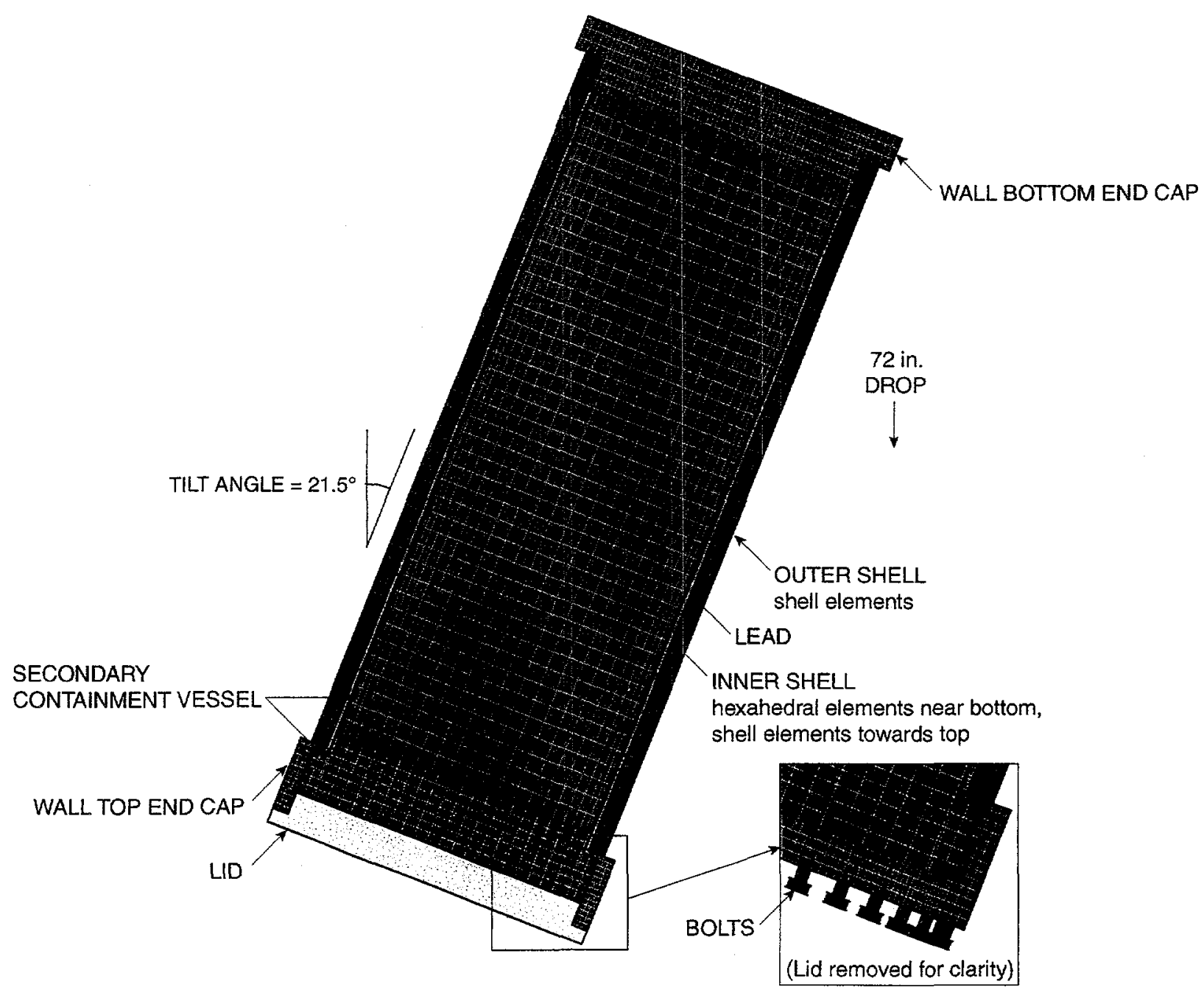

Figure 2 - Finite element model for case (2), corner drop onto the lid 


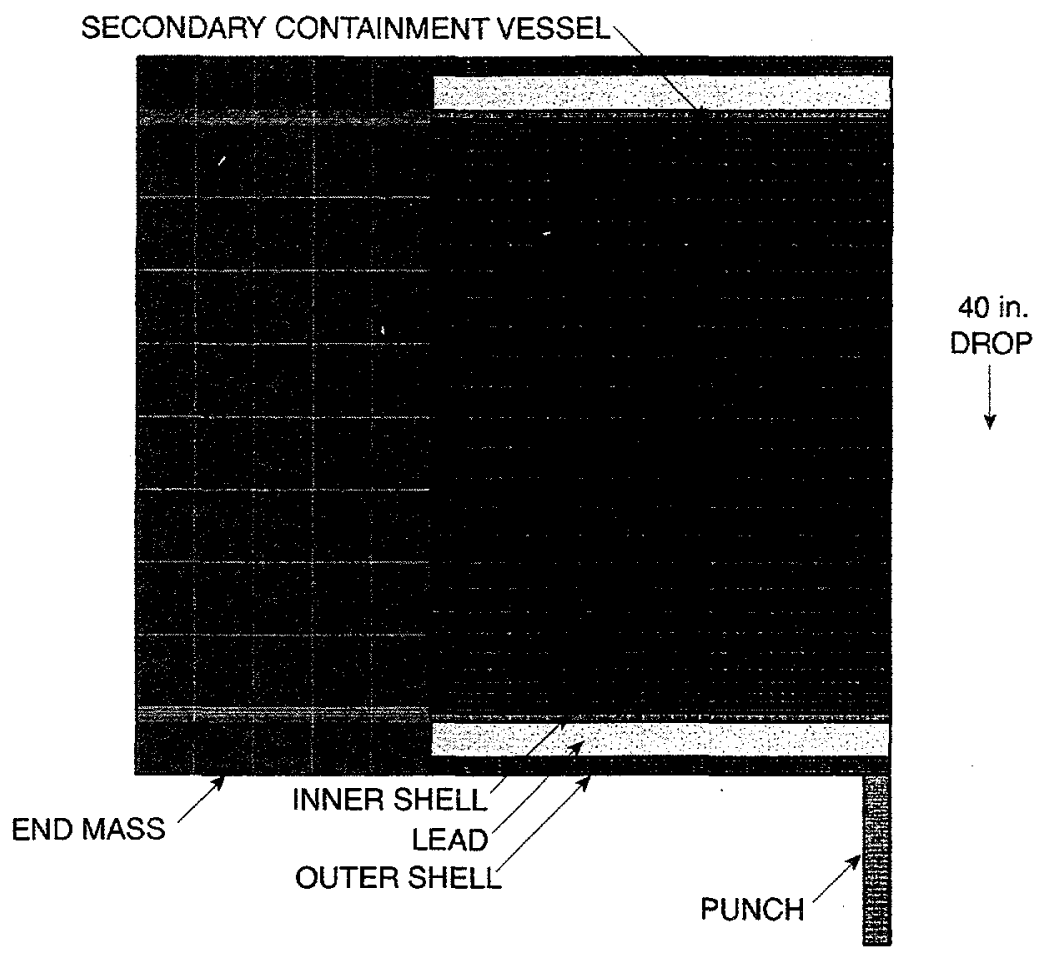

Figure 3 - Finite element model for case (3), horizontal drop onto a punch

end mass. This approach will lead to a slight over-estimation of the stresses in the vicinity of the punch and a slight under-estimation of the maximum deflection into the cask inerior. The errors are small because the deflections and stresses in a real cask at the distance from the punch that the end mass is placed are small. The drop height analyzed for this case was $40 \mathrm{in}$. This case represents the puncture event defined by 10CFR71.73(c)(3).

The finite element model for case (4) is shown in Fig. 4. One half of the cask was modeled to take advantage of the symmetry. The upper portions of the inner and outer shells, away from the impact corner, are modeled with shell elements. The tilt angle of the cask was again chosen to vertically align the geometric center of the cask over the impact corner of the cask. The analysis simulated a drop height of 72 in.

The finite element model for case (5) is shown in Fig. 5. The model was half-symmetric. As indicated in the figure, the tilt angle of the cask was chosen to be 5 degrees from horizontal, to allow rotation of the cask between the impact of the first trunnion and the second trunnion. Only the two trunnions nearest the ends of the cask were included, in order to represent a worst case scenario. The flat strip described for case (1) and shown in Fig. (1) was also utilized in this model. The mass of the secondary containment vessel and contents were combined and grouped into the mass of the shell walls of the secondary containment vessel. The analysis simulated a drop height of 72 in. 




Figure 4 - Finite element model for case (4), corner drop onto cask bottom

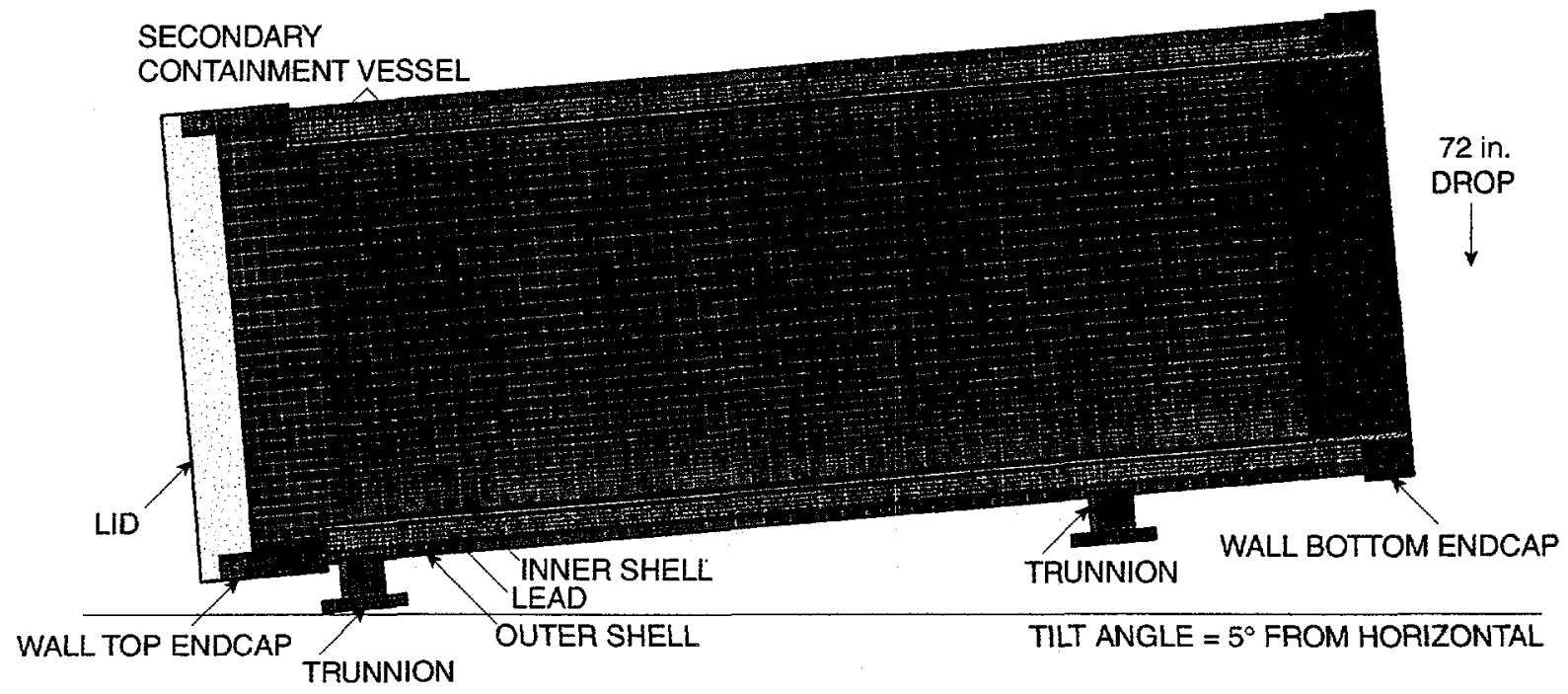

Figure 5 - Finite element model for case (5), slap-down impact onto second trunnion 


\section{Failure Prediction}

For the design of radioactive material transportation containers, there is no ASME code recognized failure criterion for inelastic analysis. The only exception to this is for puncture analyses, Code Case N-626 [2] to Section III, Division 3 of the ASME Boiler and Pressure Vessel Code [3], which provides guidance for the allowable stress in the containment boundary. Using this approach for a stainless steel shell, the stress in the inner containment shell is not to exceed $0.9 S_{u}$, where $S_{u}$ is the ultimate engineering stress at failure, and is defined to be $70000 \mathrm{psi}$ for stainless steel. This limit is believed to be quite conservative based on experimental coupon testing of $304 \mathrm{~L}$ stainless steel, as reported in Ref. 4 . A plot of stress vs. strain for $304 \mathrm{~L}$ stainless steel is shown in Fig. 6. Because the finite element code gives results in terms of true stress and true

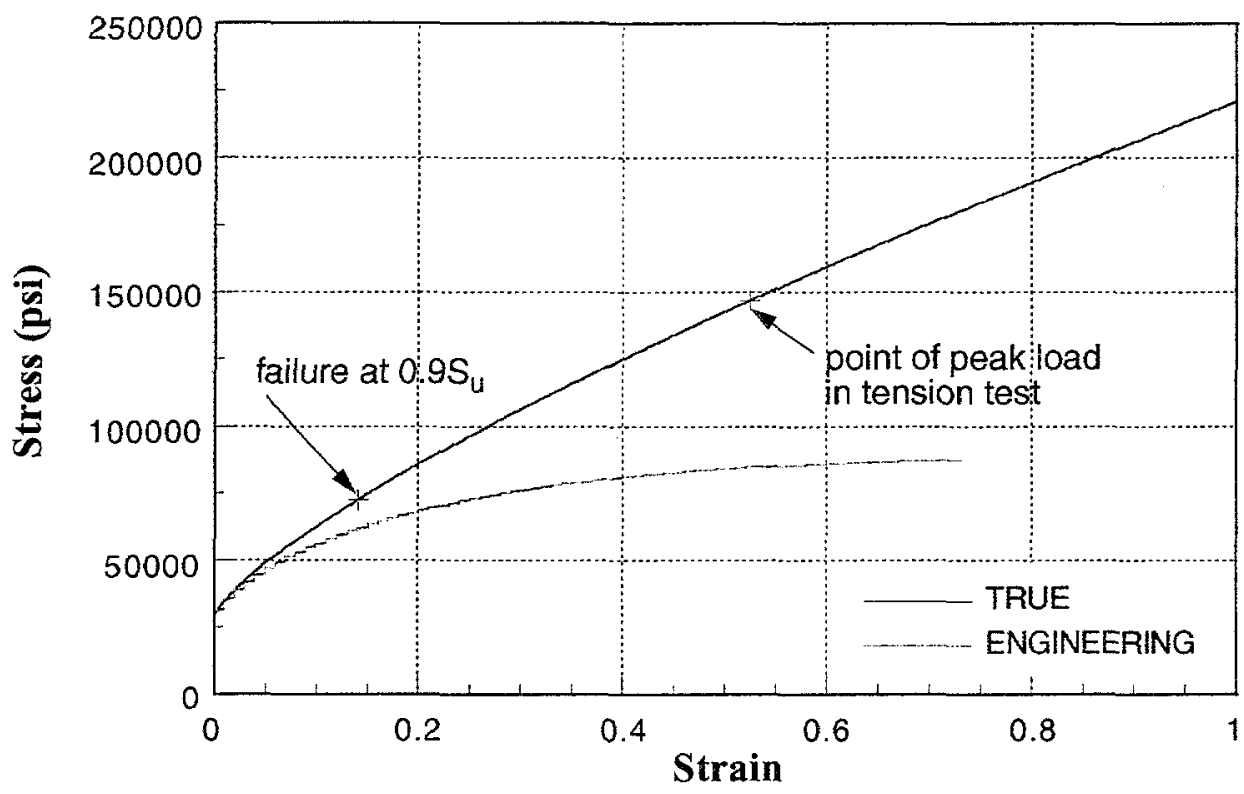

Figure 6 - Stiffness of 304L stainless steel

strain, the failure criterion of $0.9 S_{u}$ is shown on the true stress/true strain curve. The true stress at failure corresponding to $0.9 S_{u}$ is $72500 \mathrm{psi}$. The value for the point of peak load in a tension test was taken from Ref. 4 . The true stress corresponding to the peak load in a tension test is 147000 psi. This value will be used as a failure criterion for the outer shell. A more detailed assessment of the utility of the ASME Code Case can be found in Ref. 5.

\section{Results}

Finite element results for case (1), the side drop onto the lifting trunnion, are shown in Fig. 7. The maximum true stress in the model occurs in the trunnion. Although the value of this stress seems high, $135600 \mathrm{psi}$, this is due primarily to compression, so tensile failure is not expected. In the inner and outer shells, the maximum true stresses are $60850 \mathrm{psi}$ and $119000 \mathrm{psi}$, respectively. The inner shell meets the $0.9 S_{u}$ criterion that the true stress be below 72500 psi, implying that the inner shell will not fail. The outer shell, which is not required to meet the $0.9 S_{u}$ criterion, does not fail according to the tension test criterion which states that the maximum stress be below 
147000 psi. Additionally, the maximum stress in the outer shell occurs at a point of some compression between the shell and the trunnion. The remainder of the shell experiences even lower stresses. Also of concern for this case was the magnitude of the maximum deflection into the shell. This deflection is illustrated in Fig. 7, and found to be 2.2 in.

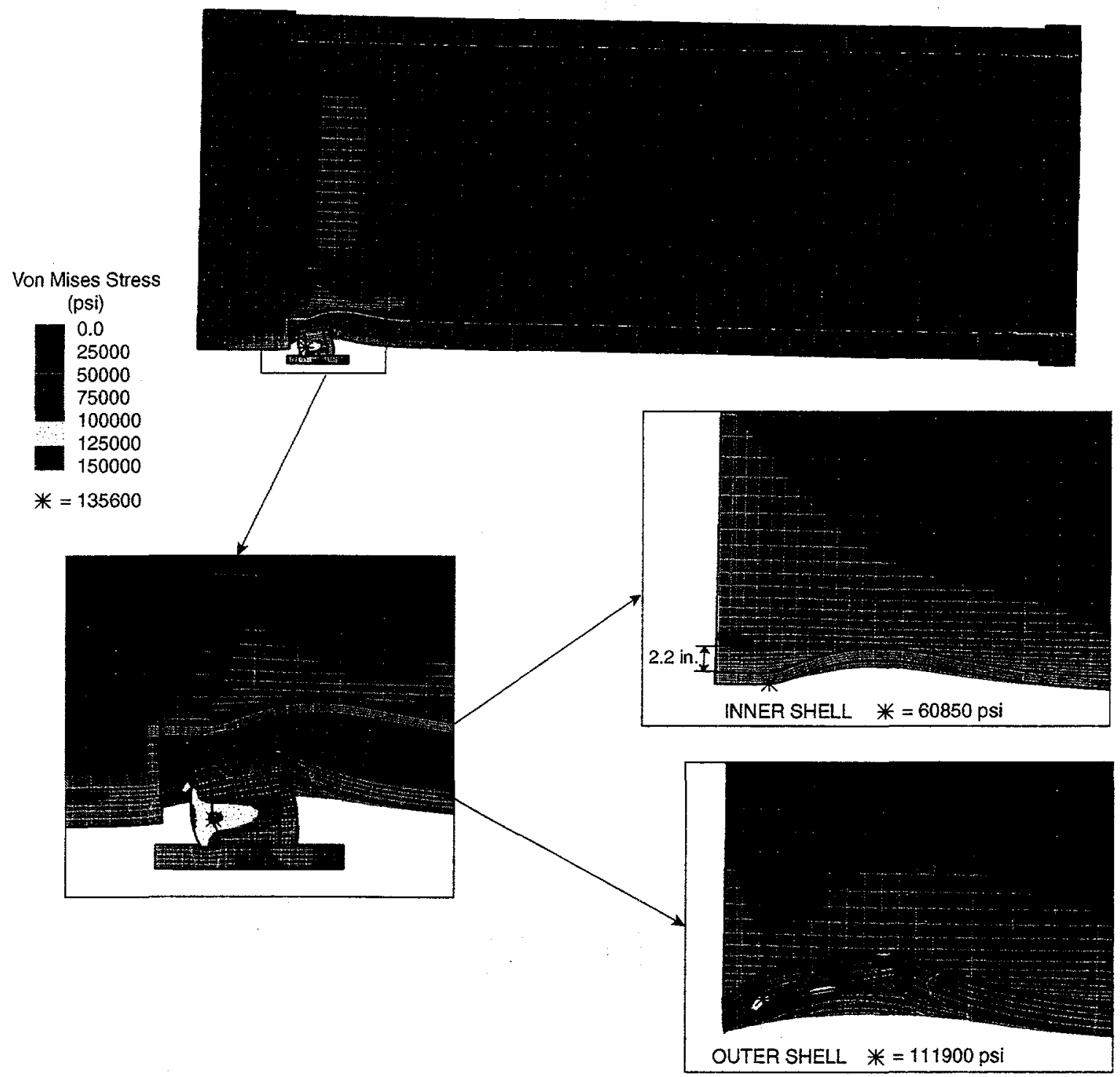

Figure 7 - Results for case (1), side drop onto the lifting trunnion

The results for case (2), the corner drop onto the lid, are shown in Figs. 8, 9, and 10. In Fig. 8, the global deformations and stresses are shown. For this case, the main concern was that the cask remain sealed in the region of the o-ring, which is located between the lid and the wall top end cap. A detail of this area is shown in Fig. 9. The opening displacement was calculated from the finite element results for a location on the cask nearest the impact corner. The displacement is shown in Fig. 9. A maximum opening displacement of 0.34 in. is predicted, which implies that the cask seal would leak after a corner impact onto the lid. While examining the results, it was noted that some of the bolts appeared to stretch substantially, perhaps even beyond their expected 


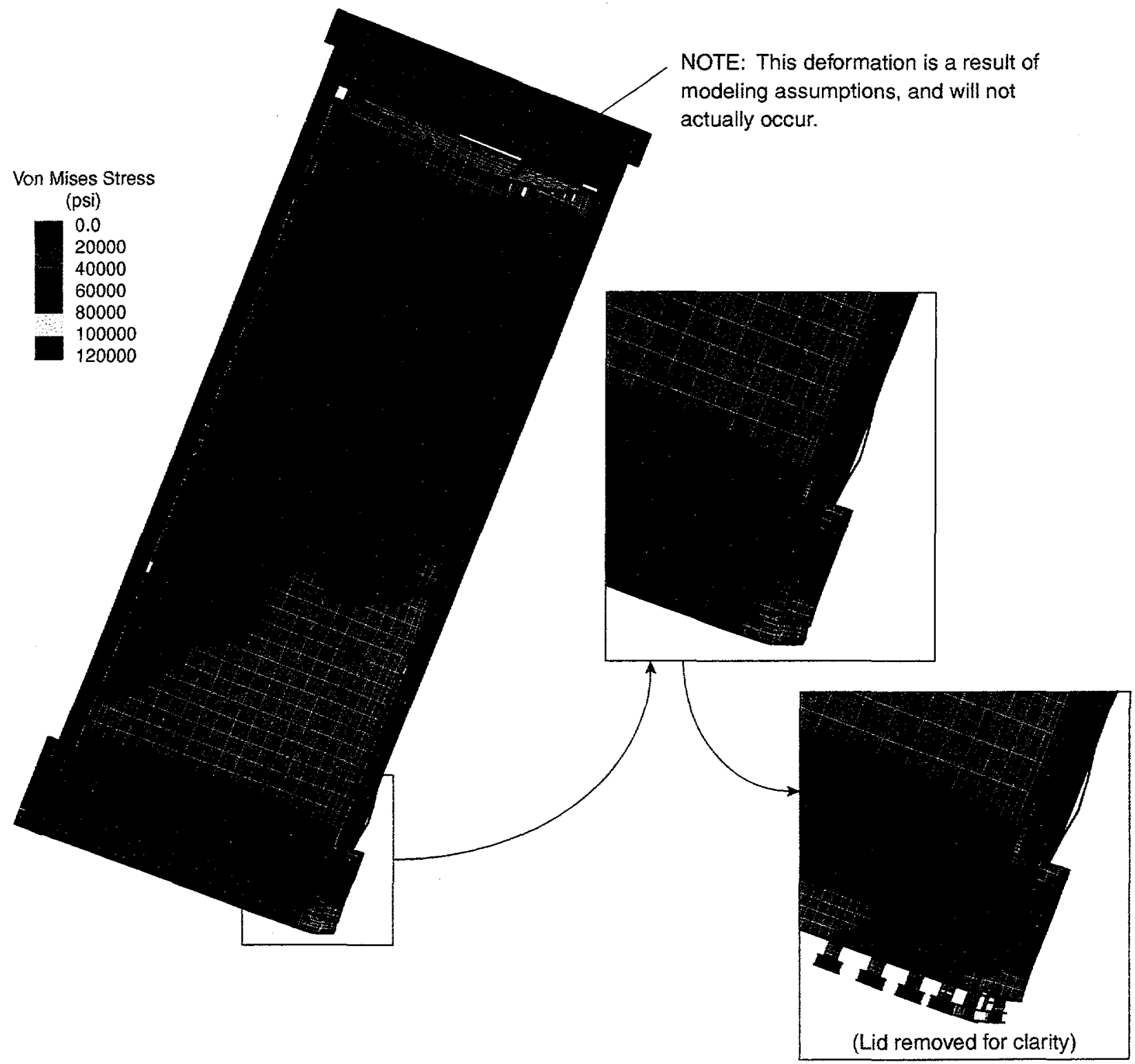

Figure 8 - Results for case (2), corner drop onto the lid

strain to failure. This bolt stretching is illustrated in Fig. 10 for 6 bolts around the circumference of the cask. Notice that the bolts labeled 1,2,3, and 4, located furthest from the point of impact, experience stretching on the order of 0.75 in. This is a result of the contents exerting a downward force on the lid, which in this configuration is resisted entirely by the bolts. Although an exact failure criterion for the bolts is not included here, the magnitude of the bolt deformations for this case indicate a cause for concern against possible bolt failure.

The finite element results for case (3), the horizontal drop onto a punch, are shown in Fig. 11. The maximum true stress in the inner shell is $51480 \mathrm{psi}$, which is well below the failure value of 72500 psi suggested by the $0.9 S_{u}$ criterion. Therefore, the inner shell is not expected to fail. The outer shell maximum true stress is $96390 \mathrm{psi}$, which is greater than the 72500 allowed by the $0.9 S_{u}$ criterion, but the outer shell is not required to meet this criterion. The stress in the outer shell is lower than the maximum stress of 147000 psi allowed by the tension test criterion, so the outer 


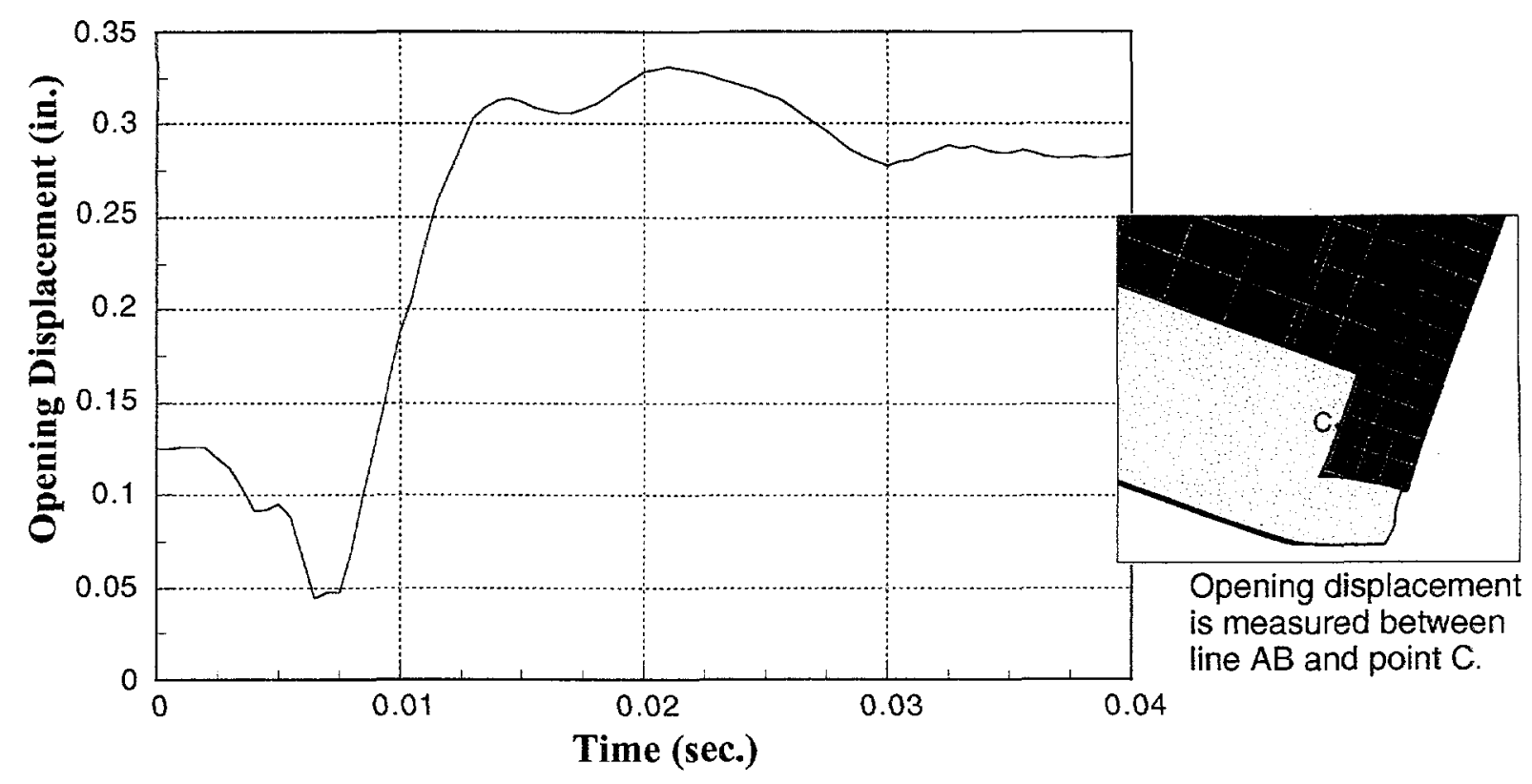

Figure 9 - Opening displacement at o-ring location for case (2), corner drop onto the lid

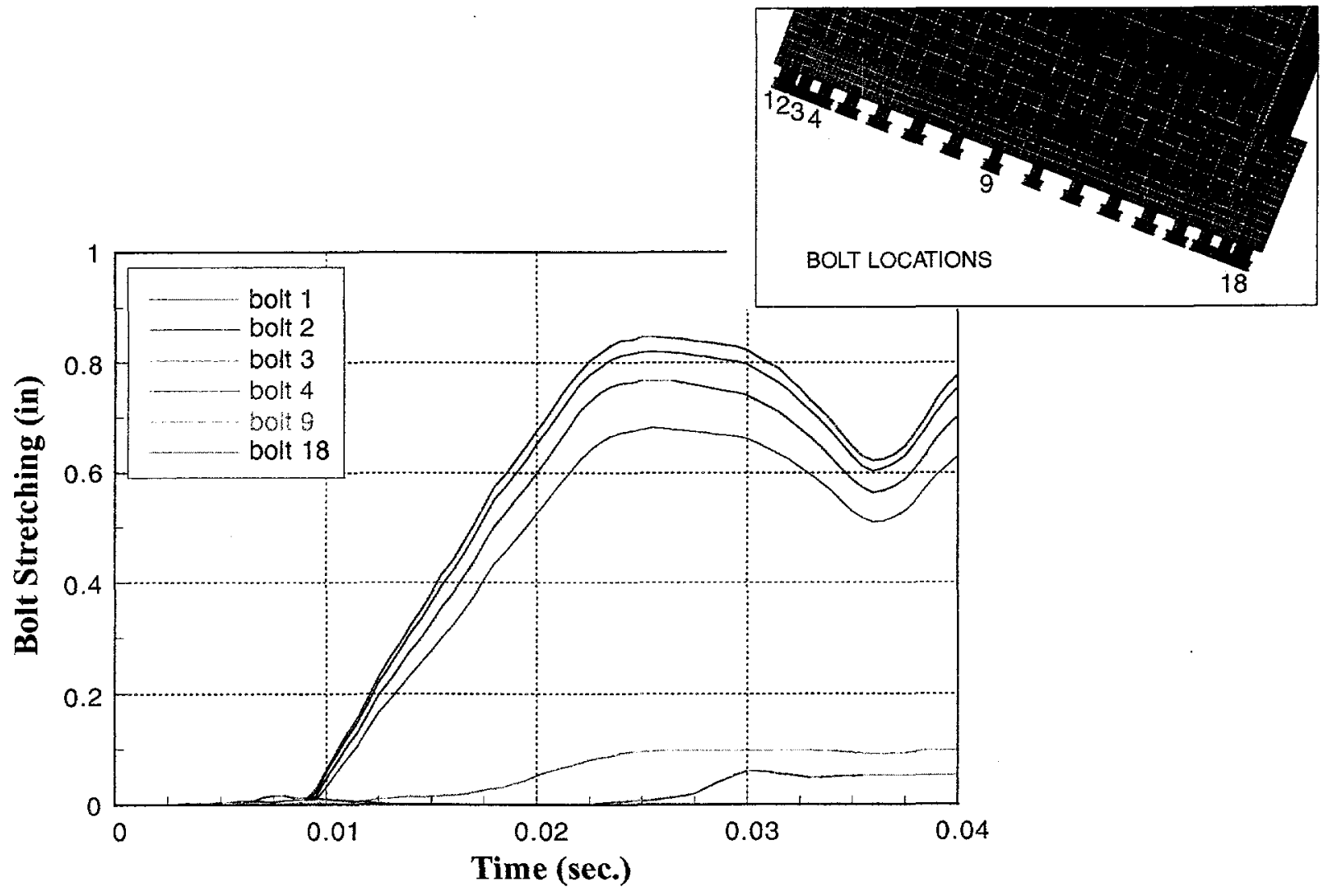

Figure 10 - Bolt stretching results for case (2), corner drop onto the lid 

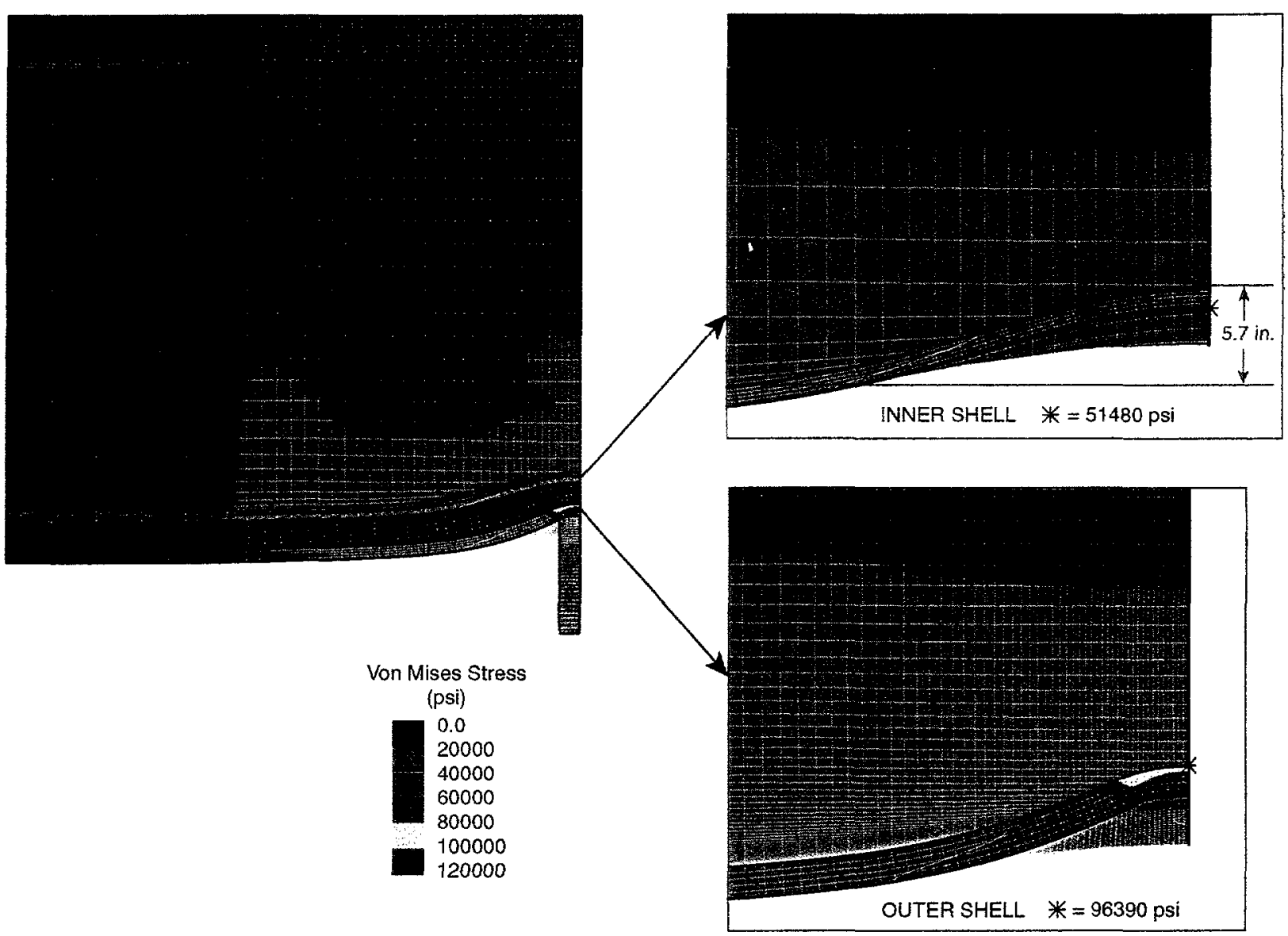

Figure 11 - Results for case (3), horizontal drop onto a punch

shell is not expected to fail either. The maximum inward deflection of the shell is 5.7 in., as shown in Fig. 11.

Results for case (4), a corner drop onto the cask bottom, are shown in Fig. 12. Stresses in the outer shell were the concern for this configuration, particularly the stresses in a longitudinal weld. Although the weld detail was not explicitly included in the model, the stresses in the outer shell were examined around the circumference of the cask. The maximum true stress, which is due primarily to compression, is shown in Fig. 12. There are no tensile stresses in the outer shell greater than $40000 \mathrm{psi}$, so failure is not expected.

Results for case (5), a slap-down impact onto a second trunnion, are shown in Figs. 13 and 14. The maximum stresses after initial impact onto the first trunnion are shown in Fig. 13. A largely compressive stress of $150000 \mathrm{psi}$ is indicated in the trunnion. The inner shell shows a maximum stress of $60620 \mathrm{psi}$, which is less than the 72500 psi maximum stress prescribed by the $0.9 S_{u}$ criterion. This implies that the inner shell will not fail. The maximum deflection into the cask is 2.2 in., as shown in Fig. 13. The maximum stress in the outer shell is 109200 psi. This value is below the maximum stress of $147000 \mathrm{psi}$ found in the tension test, so according to this criterion, the outer shell should not fail either. The maximum stresses after the secondary impact onto the second trunnion are shown in Fig. 14. The stresses in the inner shell are all below 50000 psi, so according to the $72500 \mathrm{psi}$ limit imposed by the $0.9 S_{u}$ criterion, the inner shell is not predicted to 


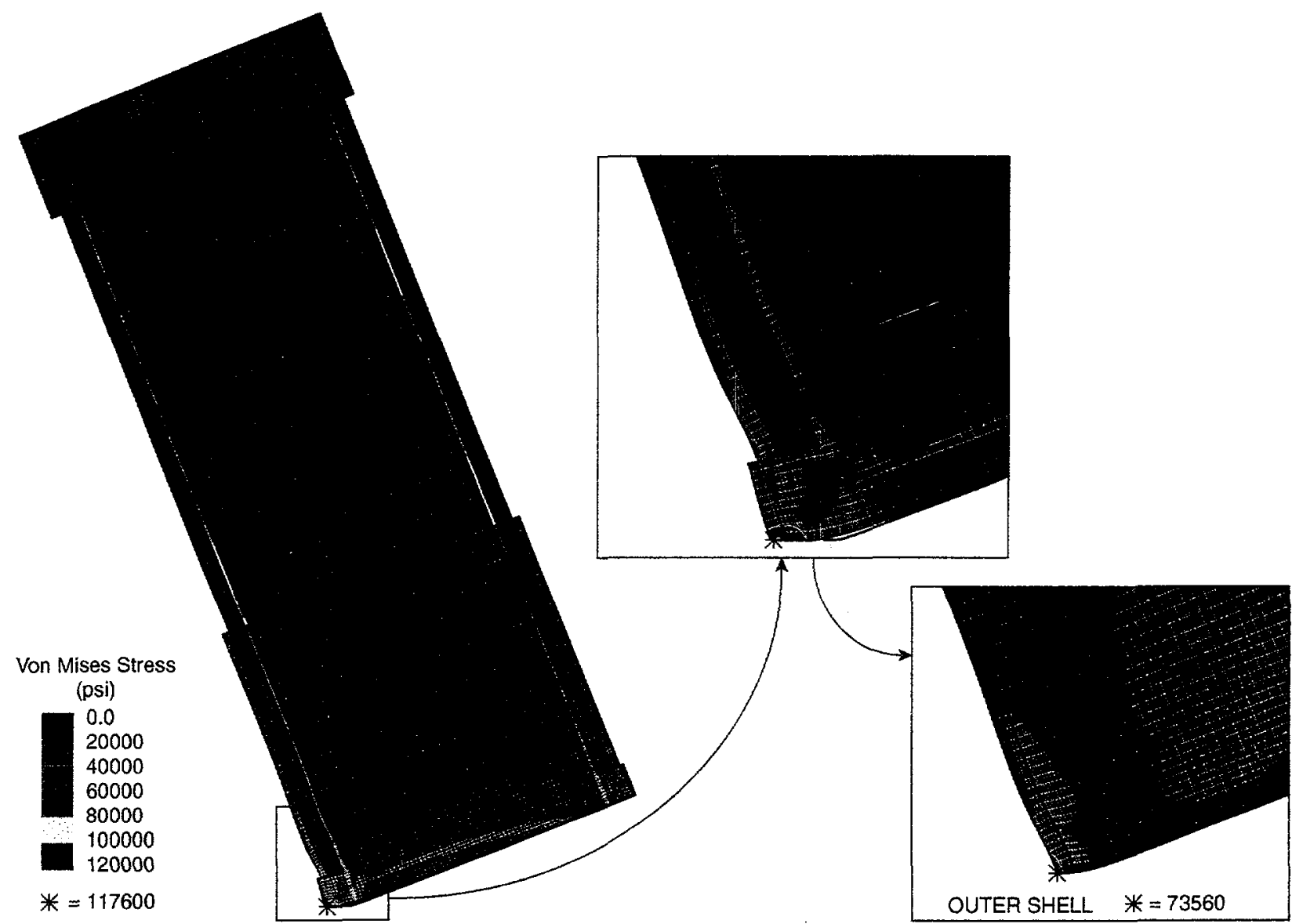

Figure 12 - Results for case (4), corner drop onto cask bottom

fail. The stresses in the outer shell are all below 75000 psi, so comparison with the tension test maximum stress of 147000 psi implies that the outer shell will not fail. The maximum deflection into the interior of the cask is 6.8 in., as shown in Fig. 14.

\section{Accelerations}

Rigid body acceleration time histories for each case are shown in Figs. 15-19. Accelerations were found for the center of gravity of each cask. The finite element code used outputs the total kinetic energy of the model throughout the analysis. From this data, a velocity time history can be derived, and numerical differentiation of the velocity time history results in the acceleration time history. For the cases where the impact point occurs under the center of gravity this procedure provides fairly accurate results up to the point of minimum kinetic energy. For the cases where the impact point is not below the center of gravity, there will be rotational kinetic energy as well as translational kinetic energy. Approximations as to the magnitude of the rotational component of the total kinetic energy were made and the velocity time histories were determined from the translational kinetic energy. 


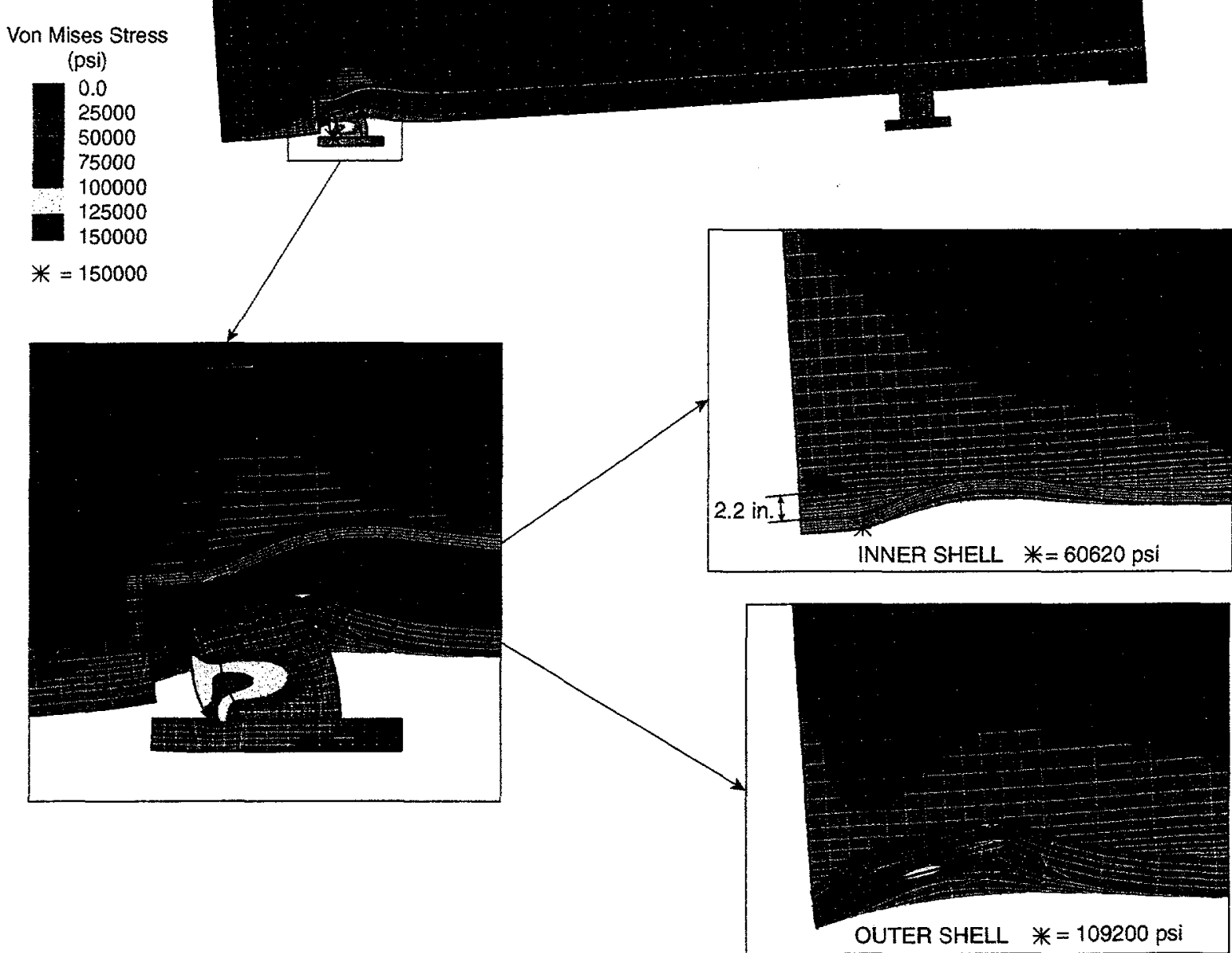

Figure 13 - Results after impact of first trunnion for case (5), slap-down impact onto second trunnion

\section{Summary and Conclusions}

Five possible handling accidents were analyzed using an explicit dynamic finite element analysis with nonlinear material properties. One drop was from a height of $40 \mathrm{in}$. onto a puncture pin, while all other drops were onto an unyielding surface from a height of $72 \mathrm{in.}$ Note that a $72 \mathrm{in.}$ drop onto an unyielding surface is outside of the regulatory envelope for transportation packaging of this size. For the cases where cask puncture was of concern, including case (3), a horizontal drop onto a puncture pin, case (1), a side drop onto a trunnion, and case (5), a drop with a slapdown onto a second trunnion, the stresses in the inner and outer shell were evaluated for possible 


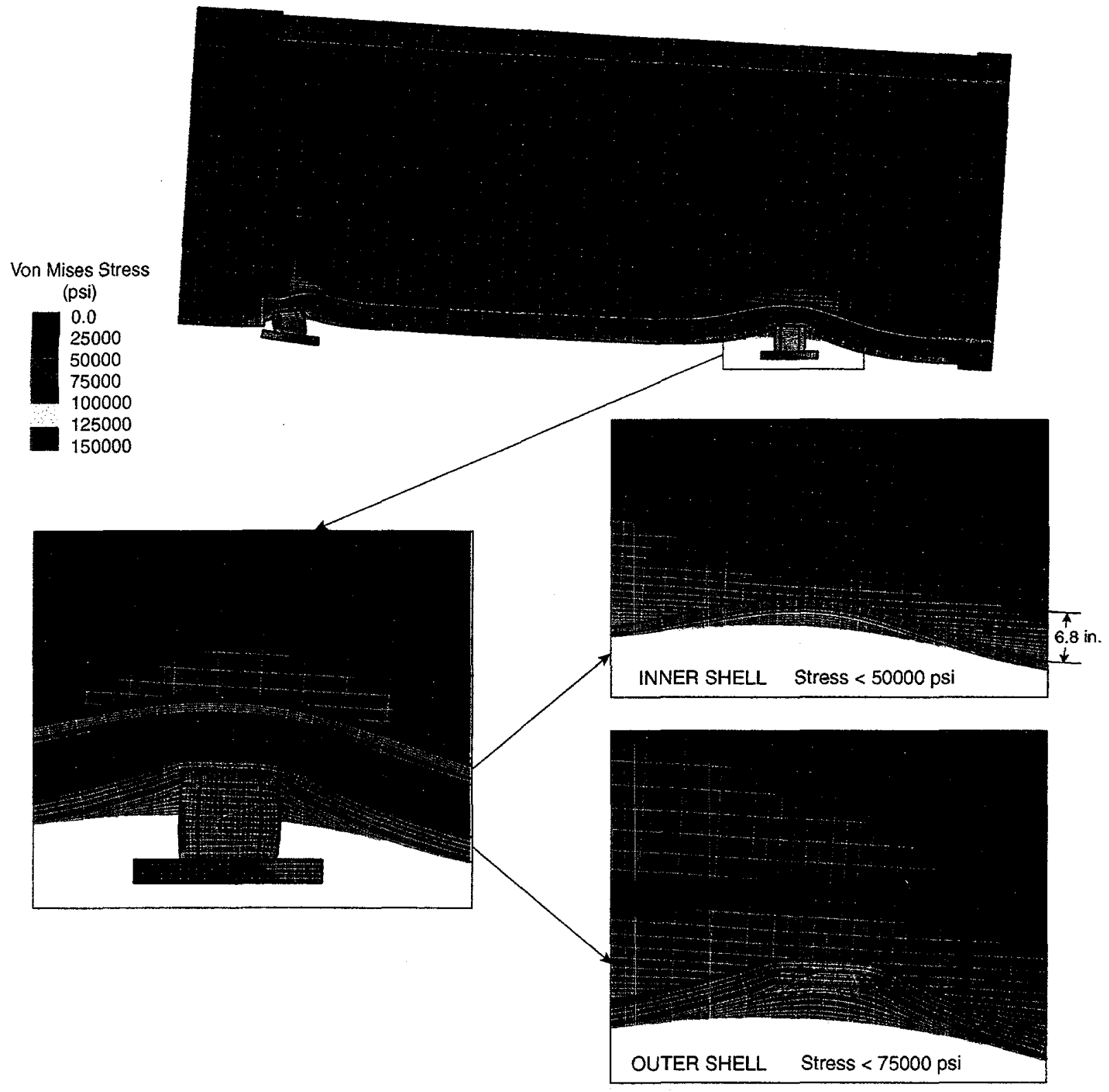

Figure 14 - Results after impact of second trunnion for case (5), slap-down impact onto second trunnion

failure. None of these accidents resulted in failure of either the inner or outer shells. Deflection into the shell was significant however, ranging from 2.2 to 6.8 in. For case (4) where the bottom corner of the cask made initial impact, stresses in the outer shell were evaluated against failure. No failure was predicted. For case (2) where the cask was dropped onto the edge of the lid, the opening displacement in the region of the o-rings was evaluated. This displacement was found to be significant, suggesting that the o-ring seals may possibly leak after this event. The stretching of the bolts was also evaluated, and found to be excessive, on the order of $0.75 \mathrm{in}$. This stretching behavior is great enough to cause concern and may indicate that the bolts would actually fail in tension. 


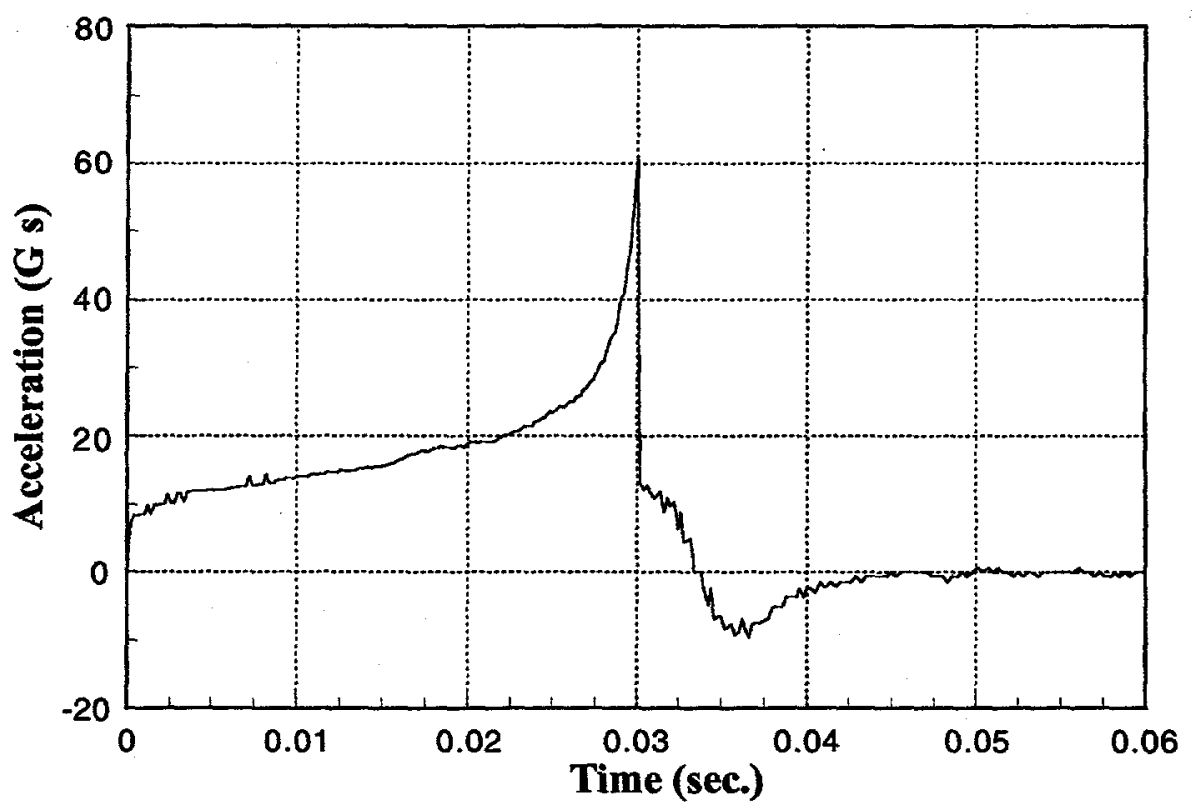

Figure 15 - Acceleration for case (1), side drop onto the lifting trunnion

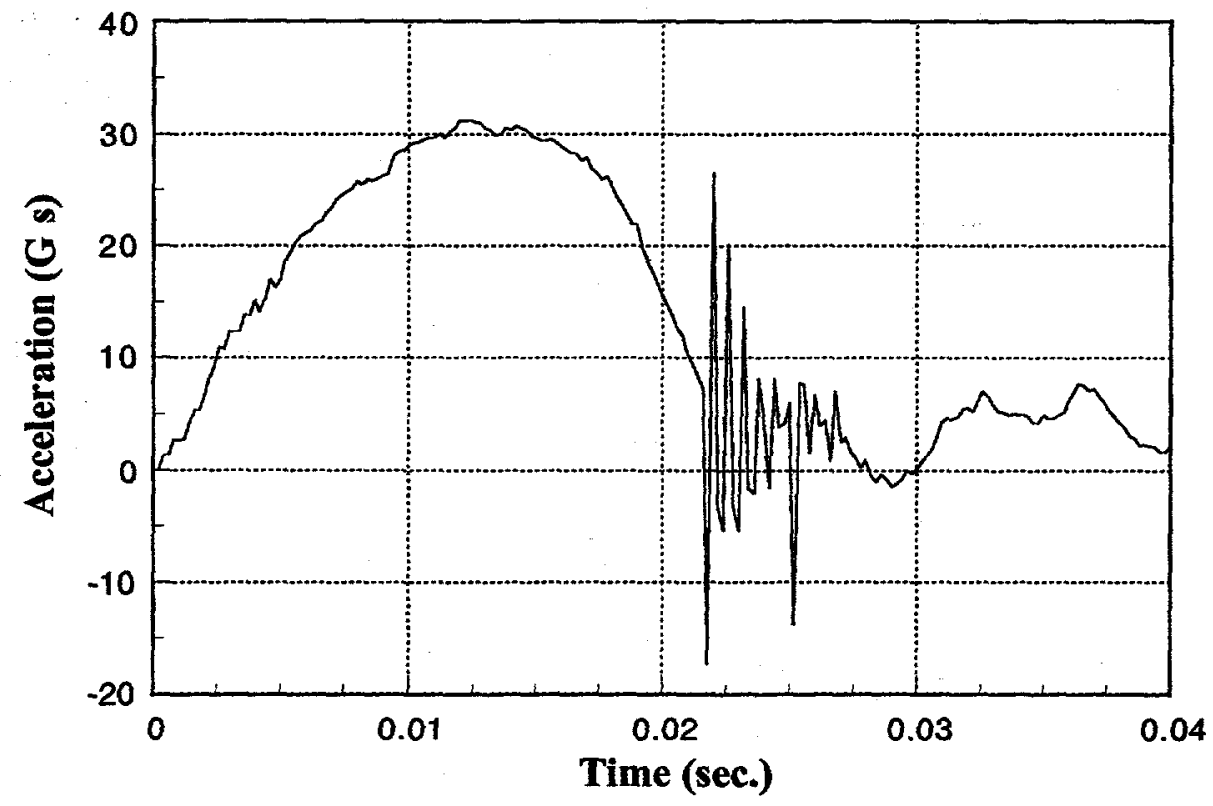

Figure 16 - Acceleration for case (2), corner drop onto the lid

For the five accident cases analyzed, the integrity of the cask is predicted. Other accident scenarios may be more or less severe. Modifications to the prototype NSNFP cask may result in significantly different stresses to the cask 


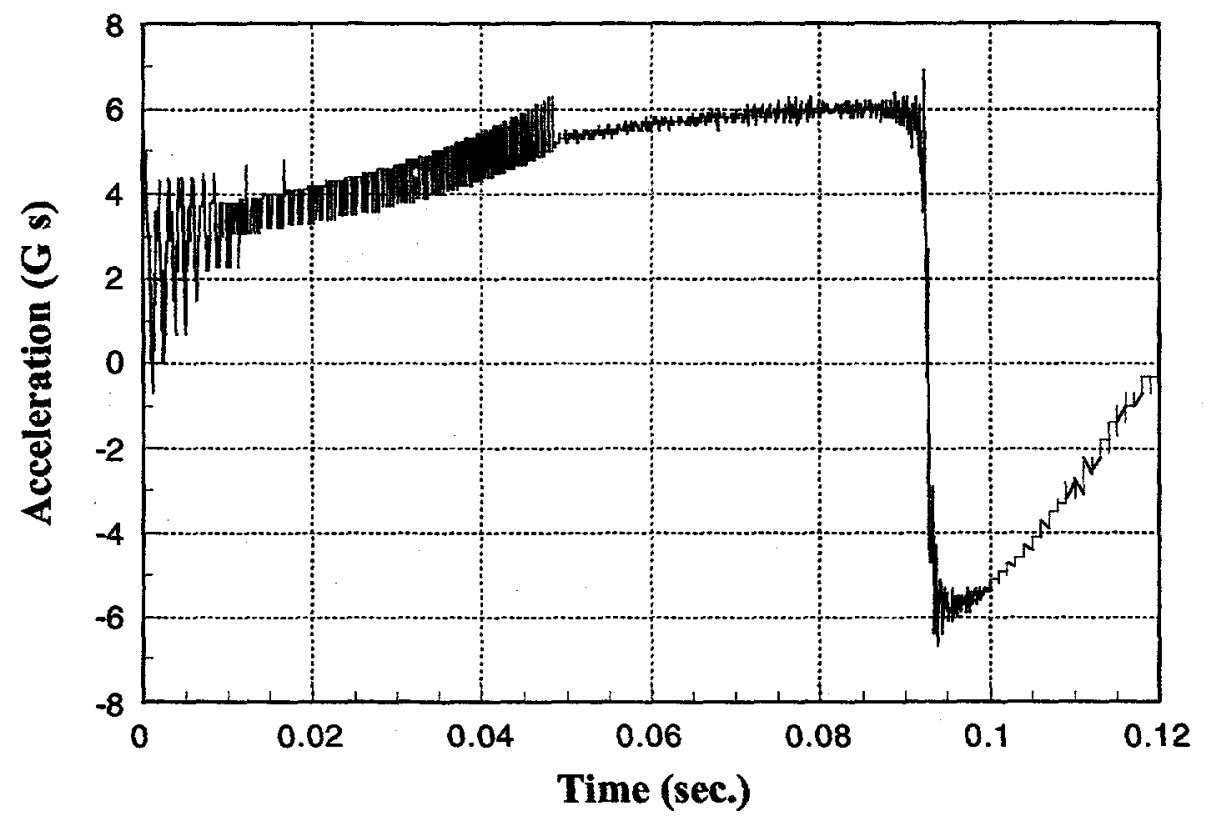

Figure 17 - Acceleration for case (3), horizontal drop onto a punch

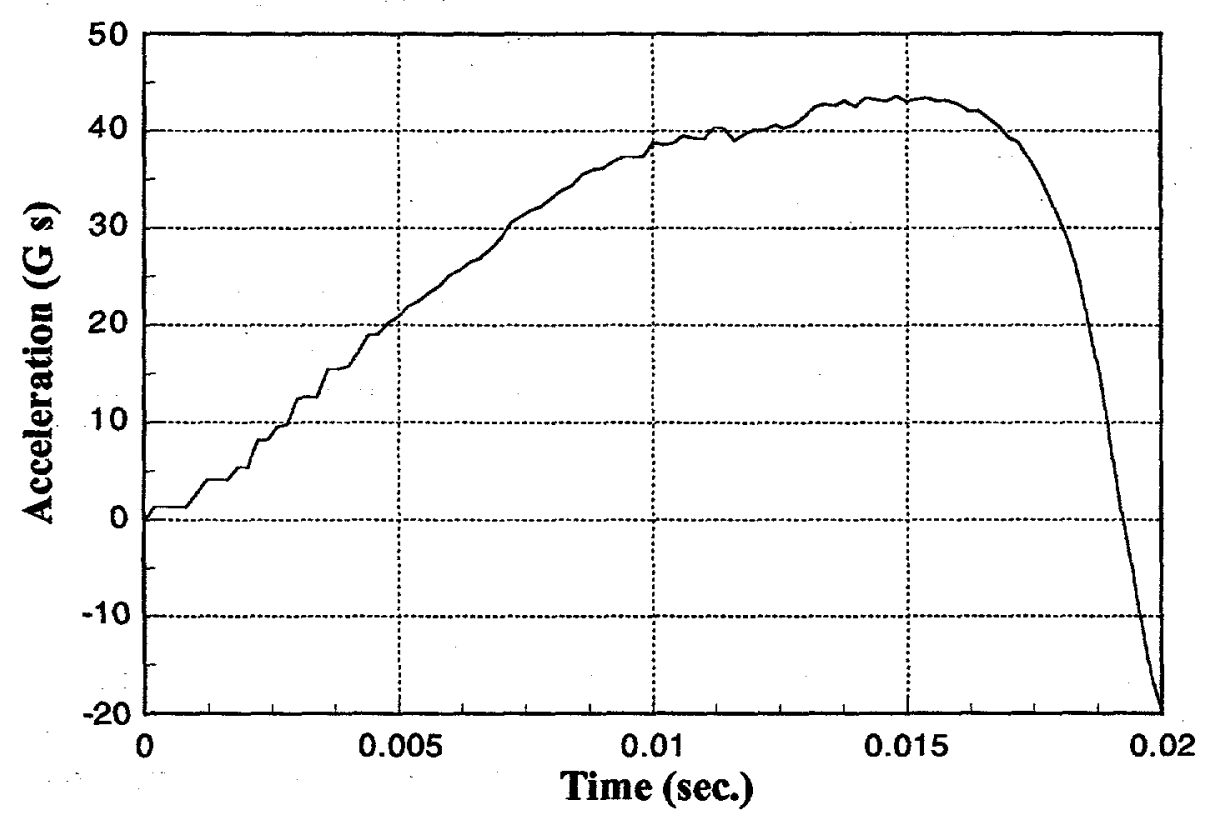

Figure 18 - Acceleration for case (4), corner drop onto cask bottom

\section{References}

1. Taylor, L. M., and Flanagan, D. P., PRONTO-3D: A Three-Dimensional Transient Solid Dynamics Program, SAND87-1912,1989.

2. ASME Boiler and Pressure Vessel Code, Code Case N-626, American Society of Mechanical Engineers, New York, 1998. 


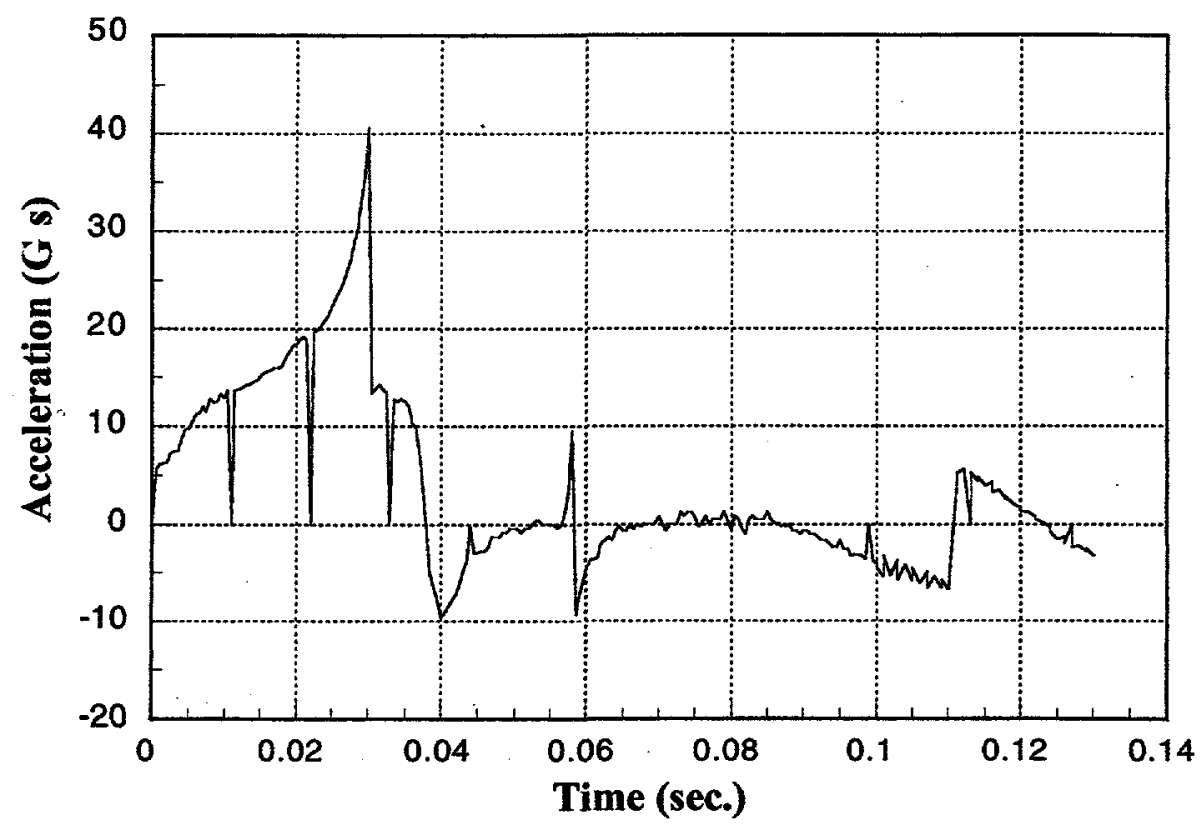

Figure 19 - Acceleration for case (5), slap-down impact onto second trunnion

3. ASME Boiler and Pressure Vessel Code, Section III, Division 3, American Society of Mechanical Engineers, New York, 1998.

4. Wellman, G.W., and Salzbrenner, R. "Quasistatic Modeling and Testing of Exclusion Region Barrier Mock-Ups", SAND92-0024,1992.

5. Ammerman, D. J. and Breivik, N. L. "Use Of Inelastic Analysis In Cask Design," Proceedings of the Embedded Topical Meeting on DOE Spent Nuclear Fuel and Fissile Material Management, San Diego, CA, June 2000, pp. 353-358. 


\section{Distribution}

T. L. Bridges

P.O. Box 1625

Idaho Falls, ID 83415

S. C. Gladson

P.O. Box 1625

Idaho Falls, ID 83415

T. Hill

P.O. Box 1625

Idaho Falls, ID 83415
A.L. Lengyel (10)
P.O. Box 1625
Idaho Falls, ID 83415
D. L. Pincock
P.O. Box 1625
Idaho Falls, ID 83415

\section{Sandia Internal Distribution}

$\begin{array}{lll}10 & \text { MS 0718 } & \text { D. J. Ammerman } \\ 10 & \text { MS 0847 } & \text { N. L. Breivik } \\ 1 & \text { MS 0847 } & \text { R. A. May } \\ 1 & \text { MS 0716 } & \text { P. E. McConnell } \\ 1 & \text { MS 0716 } & \text { C. E. Olson } \\ 1 & \text { MS 0718 } & \text { K. B. Sorenson } \\ 25 & \text { MS0718 } & \text { TTC Library } \\ 1 & \text { MS 9018 } & \text { Central Technical Files, 8940-2 } \\ 2 & \text { MS 0899 } & \text { Technical Library, 9616 } \\ 1 & \text { MS 0612 } & \text { Review \& Approval Desk, 9612 } \\ & & \text { For DOE/OSTI }\end{array}$

